\title{
Чай в традиционной культуре калмыков и тувинцев
}

\author{
Татьяна И. Шараева \\ Калмыцкий научный центр РАН, Российская Федерация, \\ Елена В. Айыжы \\ Тувинский государственный университет, Российская Федерация
}
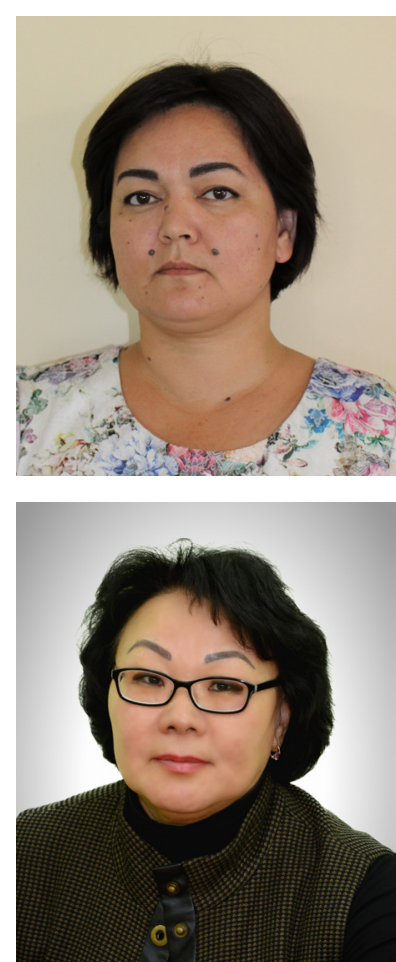

В статье анализируются традиции и современное состояние употребления у тувинцев и калмыков - молочного чая. Его считали и считают его продуктом первой необходимости, жизненно важным продуктом питания, лечебным средством, и в настоящее время - этническим маркером.

Рассматриваются история распространения чая, сложивщиеся традиции его приготовления, охарактеризованы практики использования в быту и обрядовой сфере калмыков и тувинцев. Выявлено, что использование и значение молочного чая связано с ведением экстенсивного животноводства и традиционным мировоззрением, с сакральным значением молока как «белого», «священного продукта».

Способы приготовления традищионного молочного чая хальмг изә у калмыков и сүттүг шай у тувинцев имеют определенные различия в способе приготовления заварки, очередности ингредиентов, способе смешивания готового чая и т. д.

Ключевые слова: чай; молочный чай; калмыки; тувинцы; чайная церемония; традиционная обрядность; повседневность; традиционная кухня

"Исследование проведено в рамках государственной субсидии - проект «Комплексное исследование процессов общественно-политического и культурного развития народов Юга России» (регистрационный номер ААAА-A19-119011490038-5).

\section{Для цитирования:}

Шараева Т. И., Айыжы Е. В. Чай в традиционной культуре калмыков и тувинцев [Электронный ресурс] // Новые исследования Тувы. 2019, № 4. URL: https://nit.tuva.asia/nit/article/view/890 (дата обращения: дд.мм.гг.). DOI: 10.25178/nit.2019.4.12

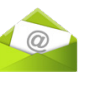

Шараева Татьяна Исаевна - кандидат исторических наук, старший научный сотрудник отдела истории, археологии и этнологии Калмыцкого научного центра Российской академии наук. Адрес: 358000, Россия, г. Элиста, ул. им. И. К. Илишкина, д. 8. Тел.: +7 (84722) 3-55-06. Эл. адрес: sharaevati@yandex.ru

ORCID ID: 0000-0002-2242-5136

Айыжы Елена Валерьевна - кандидат исторических наук, доцент кафедры всеобщей истории археологии Тувинского государственного университета. Адрес: 667000, Россия, г. Кызыл, ул. Ленина, д. 32. Тел.: +7 (394-22) 2-19-69. Эл. aдрес: aiygy@mail. ru ORCID ID: 0000-0002-4289-3543

Sharaeva Tatyana Isayevna, Candidate of History, Senior Research Associate, Department of History, Archaeology and Ethnology, Kalmyk Scientific Center of the Russian Academy of Sciences. Postal address: 8 Ilishkin St., 358000 Elista, Russian Federation. Tel.: +7 (84722) 3-55-06. E-mail: sharaevati@yandex.ru

Aiyzhy Elena Valerievna, Candidate of History, Associate Professor, Department of World History, Tuvan State University. Postal address: 32 Lenin St., 667000 Kyzyl, Republic of Tuva, Russian Federation. Tel.: +7 (394-22) 2-19-69. Email: aiygy@mail.ru 


\title{
Tea in the traditional culture of the Kalmyks and Tuvans"
}

\author{
Tatyana I. Sharaeva \\ Kalmyk Scientific Center of the Russian Academy of Sciences, Russian Federation, \\ Elena V. Aiyzhy \\ Tuvan State University, Russian Federation
}

\begin{abstract}
The article analyzes the traditions and current state of consumption of milk tea among the Tuvans and Kalmyks. It was - and still is - considered a most required product characterized as vital, therapeutic, and, currently, ethnically essential.

The paper examines the history of tea distribution, the established traditions of its preparation, depicts practices of its use in household and ceremonial activities of Kalmyks and Tuvans. The study reveals the use and significance of milk tea is associated with the introduction of extensive livestock breeding and the traditional worldview, with the sacred meaning (and value) of milk as a 'white', 'sacred' product.

Methods of preparation of traditional milk tea - 'khalmg tsä' of the Kalmyks and 'süttüg shay' of the Tuvans - have certain differences in terms of brewing, order of ingredients, final stirring techniques, etc.
\end{abstract}

Keywords: tea; milk tea; Kalmyks; Tuvans; tea ceremony; traditional rites; everyday life; traditional cuisine

"The reported study was funded by government subsidy - project name 'Socio-Political and Cultural Development of South Russia's Peoples: a Comprehensive Research of Respective Processes' (registration number AAAA-A19-119011490038-5).

\section{For citation:}

Sharaeva T. I. and Aiyzhy E. V. Tea in the traditional culture of the Kalmyks and Tuvans. The New Research of Tuva, 2019, no. 4 [online] Available at: https://nit.tuva.asia/nit/article/view/890 (access date: ...). DOI: 10.25178/nit.2019.4.12

\section{Введение}

По мнению С.А. Арутюнова: «пища - это тот элемент материальной культуры, в котором более других сохраняются традиционные черты, с ним более всего связаны представления народа о своей национальной специфике» (Арутюнов, 2001: 10). В этнической культуре любого народа пищевые традиции, сложившийся этикет, различные запреты, а также ритуалы и обряды, связанные с пищей, отражают его профанные и сакральные миры.

В повседневной жизни современных калмыков и тувинцев (в том числе тувинцев Монголии и Китая) чай и приготовленный на его основе молочный чай являются неотъемлемой частью национальной культуры, выразительной формой гостеприимства со сложившейся церемонией, часто дополняемой вербальным компонентом в виде благопожеланий. В культурных традициях обоих народов чай имеет большое значение в повседневной и обрядовой сфере: чай дарят в качестве подарка; несут вместе с гостинцами, когда идут в гости; чай, в том числе молочный чай, входит в состав различных подношений в обрядах календарного и жизненного циклов и т.д. Свежеприготовленный горячий молочный чай по традиции используют в качестве своеобразного терморегулятора: в холодное время с помощью горячего чая согреваются, а в жару чай употребляют для «охлаждения» ${ }^{1}$ и утоления жажды.

И калмыки, и тувинцы относятся к молочному чаю как к лекарству, применяя его в лечении различных заболеваний. Крепко заваренный чай без добавления молока используют для лечения глазных, кожных, желудочно-кишечных болезней. Молочный чай считается отличным средством для увеличения лактации, восстановления сил после различных заболеваний. От постоянного употребления молочного чая калмыки и тувинцы настолько зависимы, что свою слабость и недомогание, болезненное

1 Эффект охлаждения в сильную жару достигается за счет повышенного потоотделения при употреблении горячего чая, происходит естественное охлаждение кожи человека при выпаривании жидкости на ее поверхности. 
состояние часто объясняют недостаточным употреблением чая или его отсутствием в рационе питания даже на непродолжительное время: «Мало пил(а) чаю - сил нет».

У калмыков есть легенды, отражающие восприятие молочного чая как лекарства. Так, согласно одной из них, Зункава ${ }^{1}$, тяжело болевший много лет, обратился к лекарю, который порекомендовал ему в качестве лекарства пить на голодный желудок крепкий молочный чай с солью в течение семи дней. Через неделю Зункава действительно стал чувствовать себя окрепшим и здоровым, болезнь окончательно покинула его. Это произошло 25 числа первого зимнего месяца по лунному календарю. С этого дня Зункава повелел калмыкам отмечать Зул как «Праздник продления лет», именно поэтому в этот день все калмыки стали прибавлять по одному году к своему возрасту, возжигать лампадки на алтарях и совершать подношение молочным чаем (Семь звезд ..., 2004: 75-76). И сегодня у калмыков сохраняется традиция произносить фразу «Уусн цәәтн аршан болтха!» (букв. «Пусть выпитый Вами чай станет аршаном-целебным напитком!») перед началом чаепития.

На значение чая в современных культурных традициях калмыков и тувинцев указывает тот факт, что молочным чаем принято встречать и угощать гостей даже у трапа самолета и на вокзале. На многих культурно-массовых мероприятиях, проводимых в республиках, в качестве угощения непременно предлагают молочный чай. Кроме того, в обеих республиках официально празднуется «День чая»: в Республике Калмыкия - с 2012 г. проводится в третью субботу мая «День калмыцкого чая», а Республике Тыва - с 2014 г. в рамках летнего национального праздника «Наадым» проводится «Фестиваль чая»². В эти дни проводятся различные конкурсы, в ходе которых участники должны представить свои рецепты приготовления чая, знания о чайной церемонии, умение произносить на родном языке образцы устного народного творчества о чае, описание обрядовых действий с чаем во время календарных праздников и при проведении обрядов жизненного цикла. Но, к сожалению, кроме конкурсантов, использующих специальную посуду (деревянные, керамические или фаянсовые чаши), остальные участники мероприятия пьют чай из одноразовой пластиковой посуды, что является нарушением традиций, но необходимостью на такого рода массовых мероприятиях. Однако в последнее время все же участились призывы и желание участников использовать традиционную посуду на «Дне чая», что, по их мнению, будет способствовать сохранению почтительного отношения к национальному напитку.

Особое отношение у калмыков и тувинцев к молочному чаю связано не только с целебными его свойствами и традиционной уже рецептурой, но и с представлениями о молоке и его производных продуктах (масло, кумыс, пенки и т.д.) как «белой пище» - цаһан идән у калмыков и ак чем у тувинцев, которые, как считается, обладают чистотой, наделяются очищающей и воспроизводящей силой. Считается, что молочные продукты можно подносить различным покровителям человека, жилья, скота, чтобы задобрить их.

Использование молочного чая в обрядовой практике продиктовано отношением к нему как молочному напитку с сакральным значением, поэтому начало чаепития оформляется ритуальными действиями и само чаепитие предваряет начало многих обрядовых действ у тувинцев и калмыков. K тому же густой молочный чай, употребляемый с различными добавками, заменяет, по признанию калмыков и тувинцев, один прием пищи.

Цель статьи - сопоставительный анализ практик приготовления и употребления молочного чая у тувинцев в Республике Тыва и калмыков в Республике Калмыкия. Изучение и анализ материалов позволит выявить особенности в практиках приготовления и употребления чая тюрко-монгольских народов, сходство и различия в их пищевом коде. Данная тема не была ранее предметом исследования.

В нашем исследовании мы будем опираться на различные публикации по традиционной культуре калмыков и тувинцев, в которых отражены некоторые аспекты данной темы. Вопросы пищевых комплексов, в том числе приготовления и употребления чая, рассматривались многими исследователями тувинской культуры, вместе с тем в современном тувиноведении нет обобщающих исследований по истории распространения чая, его рецептуре, чайной церемонии и обрядовом

\footnotetext{
${ }^{1}$ Зункава (калм. Зунква гегән, Цонхва гегән) - так калмыки называют тибетского религиозного реформатора Цонхава Лобзанг-дракпа (1357-1419), основателя буддийской школы Гелуг («желтошапочников»).

${ }^{2}$ В целях сохранения и возрождения национальной культуры народным Хуралом (парламентом) Республики Калмыкия 31 мая 2011 г. учрежден ежегодный праздник «День калмыцкого чая», утверждён 2 июня 2011 г. и внесён в статью 1 «Закона о праздничных и памятных датах Республики Калмыкии» от 13 октября 2004 г. N 156-III-3. Впервые он состоялся 19 мая 2012 г. У тувинцев в целях сохранения национальных традиций в 2014 г. был учрежден «Фестиваль чая», проведение которого проходит в рамках национального праздника «Наадым».
} 
употреблении. Отдельные сведения о чае и молочном чае есть в работах Е. К. Яковлева (Яковлев, 1900: 46), Г. Н. Потанина (Потанин, 2003: 23-29), Г. Е. Грумм-Гржимайло (Грумм-Гржимайло, 1926: 96), Ф. Кона (Кон, 1936: 35, 115), Л. П. Потапова (Потапов, 1969: 201-202), С.И.Вайнштейна (Вайнштейн, 1961: 101-105; 1991: 137), С. Ч. Донгак (Донгак, 2018) и др., а также в сборниках и монографиях о традиционной культуре тувинцев.

В калмыковедении тематика чая представлена более широко, начиная от работ путешественников и исследователей быта калмыков, побывавших в Калмыцкой степи с XVII в., до обобщающего сборника «Пою степной нектар - пою калмыцкий чай» (Пою степной нектар ..., 2016), авторы которого предприняли попытку создать энциклопедию чайной культуры калмыков, включив в нее не только исторические и этнографические материалы, но и произведения художественной литературы. О калмыцком чае писали, например, П. И. Небольсин (Небольсин, 1852), Н. А. Нефедьев (Нефедьев, 1834), П. А. Смирнов (Смирнов, 1999), У.Э. Эрдниев (Эрдниев, 1970), П. Э. Алексеева (Алексеева, 1999), Т. Г. Борджанова (Борджанова, 2002), Е. Э. Хабунова (Хабунова, 2009) и др.

Источниковой базой исследования послужили полевые материалы авторов, собранные в 2015-2019 гг. в Республике Тува и 2015-2018 гг. в Республике Калмыкия.

\section{Распространение чая}

Родиной чая считается Китай. Оттуда он распространился торговыми путями сначала в Азии, затем попал в Европу. По мнению С.И. Вайнштейна, чай проник к кочевникам Центральной Азии из Китая только в XVI в., но очень быстро получил широкое распространение (Вайнштейн, 1991: 145).

В Россию чай попал в XVIIв. Освоение и заселение Сибири русскими переселенцами, налаживание меновых и торговых отношений с местным населением способствовало возникновению двух основных путей распространения чая - Чуйский тракт в Западной Сибири и г. Кяхта - в Восточной. Распространение чая в народной среде Европейской части страны отличалось от сибирского. Как отмечала В. А. Липинская: «Если русские переселенцы в Сибирь заимствовали навыки чаепития от коренных жителей Азиатского континента путем непосредственной их передачи и усваивали в семейном быту, то в Европейской части интерес к новому напитку шел первоначально от элитной среды. В XIX в. решением правительства чай был введен в сферу общественного питания и вошел в быт народа сначала в городе, а затем и на селе» (Липинская, 2008: 35).

Термин «чай» от северокитайского слова cha распространился в среде тюрко-монгольских народов и русских, южно-китайское слово te- стало западно-европейским названием чая. В китайском языке оба слова обозначают «молодой листочек» (Ларина, Наумова, 2008: 244).

Китайцы торговали различными сортами чая, которые получались в результате разнообразных технологических способов обработки чайных листьев: чем больше количество операций выполнялось и с большей длительностью, тем интенсивнее в конечном продукте получался цвет (зеленый, желтый, красный, черный), аромат, вкус. При сборке чайного листа отделялись только три верхних молодых листочка; сорванные лишние листочки и веточки отбраковывались при обработке. Они тоже шли в продажу и представляли низший и самый дешевый сорт, который был доступен бедным слоям населения. В Восточной Сибири он получил название шар (Липинская, 2008: 25). Чайные стебельки со старыми и поврежденными листочками и листовую крошку, которые впоследствии давали в чае резкий и терпкий вкус, прессовали в зеленые и черные брикеты в форме плитки, что послужило появлению названия кирпичный/плиточный чай. Рассыпной чай получил название «байховый» от китайского «байхоа», означающего «белая ресничка» - так китайцы называли типсы - едва распустившиеся почки, которые придавали чаю особый аромат и вкус. Чем больше типсов было в чае, тем качественнее получался сорт и тем дороже он стоил. Прессованные дешевые сорта чая расходились в Сибири и Азии, более дорогие сорта отправлялись на запад.

Первоначально тувинцы покупали чай за счет меновой торговли в Монголии, позднее стали покупать чай у китайцев в приграничных с Монголией торговых лавках, которые к началу XX в. в достаточном большом количестве находились в тогдашнем Урянхайском крае. Исследователи отмечали, что «... кочевники в обмен на скот желают среди прочих продуктов (зерно, шелк, табак и т.д.) получать еще и чай» (Тюркские народы..., 2008: 233). Тогда китайцы начали снабжать «...урянха и чаем зеленым, и черным кирпичным... Для чаепития снабдили урянхов деревянными чашками очень удобными для урянхов - и на вид красивыми - ценностью от 20 до 1-50 коп. и дороже» (Дацышен, 2011: 148, Электр. ресурс). О том, насколько ценен был чай в повседневной жизни тувинцев, говорит тот факт, что за него, 
в результате неравнозначной мены с китайскими купцами, отдавали корову или быка. Г. П. Потанин в описании своего путешествия среди тувинцев указал, что даже шаманы брали плату за камлание плиткой чая (Потанин 2003: 23)

Чай, который тувинцам привозили китайские купцы, в основном был зеленый кирпичный чай, назывался тувинцами кыдат шай - «китайский чай» или сарыг шай - «желтый чай». Это был чай грубого помола, спрессованный в двухкилограммовые кирпичи, что и послужило его названием. Покупали тувинцы у китайцев и байгуу шай - «байховый чай/сорта байхоа», но такой чай могли позволить только состоятельные люди.

Для приготовления молочного чая калмыки использовали китайский кирпичный чай, который был покрыт тонкой бумагой с нанесенным на нее иероглифом, называемый калмыками «пятилапое тавро»; этот же иероглиф, как товарный знак, ставили на чае. Кирпичный чай привозили в калмыцкие улусы из северных провинций Китая (Исторические путешествия ..., 1936: 207). Китайский чай, который был распространен у калмыков, назывался жулан цзә. Кирпичный чай был предпочтителен по ряду причин: не рассыпается при перекочевках, сильно не промокает, доступен по цене. Калмыкам его доставляли в ящиках, где каждую плитку чая багц упаковывали в фольгу. Одна плитка чая была в длину 36 см, в ширину - 16 см, высотой - 4 см, весом - немного более 2 кг. По данным Н. А. Нефедьева, кирпичный чай, который пили калмыки, «есть стебли и испорченные листочки чая обыкновенного, которые в Китае не пропадают, а посредством клейких веществ соединяются и высушенных формах, получают вид кирпича, или четвероугольной, немного продолговатой дощечки. Дощечки сии продаются в Астрахани каждая от 4 до 4 руб. 50 коп. и составляют значительный предмет торговли» (Нефедьев, 1834: 134).

\section{Способы приготовления и употребления чая у тувинцев}

У тувинцев в традиционном быту чай хранился в матерчатых мешочках (хаn) различного размера или в мешочках, сшитых мехом наружу из шкур. Мешочки привязывали к жердям жилища. Эти мешочки украшали традиционными узорами. До начала свадьбы, юрту невесты ставили на стороне жениха, а внутри нее на самом уважаемом месте юрты - истолчённый чай в кожаном мешке, украшенном различными узорами.

Для приготовления чая тувинцы использовали специальнуюутварь. В каждой семьебылидолбленные деревянные ступки: для измельчения чая и соли использовали ступку из бересты примерно 25-30 см высотой. «В каждой семье непременно имели несколько деревянных мисок-чашек (аяк) для еды, чая, кумыса, которые хранили в цилиндрах (аяк хавы) из прутьев, стянутых деревянными обручами, или в специальных мешочках из войлока. Впрочем богатые скотоводы предпочитали привозные фарфоровые китайские чашки... Для розлива чая служили высокие кувшины (домбу, хоо) - медные и деревянные. Первые покупали у китайских купцов, а деревянные (из планок), похожие по форме на металлические, изготовляли местные мастера» (Тюркские народы..., 2008: 96).

Основной способ приготовления молочного чая суттуг шай у тувинцев был следующий: необходимое количество чая измельчали в маленькой ступе пестиком и бросали в кипящую воду, давали прокипеть в течение 7-10 минут для распускания цвета, затем добавляли молоко, соль и масло. Для чая использовали молоко коров, овец, коз, кобыл, ячих, верблюдиц, а у таежных тувинцев-тоджинцев оленей. Чай необходимо было все время после закипания молока помешивать приемом «саарар» (черпают половником и с высоты поднятой руки льют обратно). Как считалось, обязательно надо было повторить эту процедуру не менее 40 раз, и, по нашему мнению, было связано с представлением о том, что хозяйка огня и хранительница домашнего очага От ээзи кыс кижи, на огне которого готовился молочный чай, имеет «сорок языков пламени» («сороказубая», «сорокаязыкая» хозяйка огня) (Бутанаев, Монгуш, 2005: 83). В зимнее время для забеливания чая использовали замороженное молоко доң сүт (Вайнштейн, 1991: 137).

Первыми порциями из свежеприготовленного утром чая тувинцы совершали подношения огню, затем по четырем сторонам света при помощи ритуальной ложки «тос-карак» с девятью отверстиями, которые, согласно мифологическим представлениям, отождествляют поклонение 9 небесам, природным стихиям и тотемным животным. Во время семейного чаепития хозяйка первую пиалу с чаем подавала хозяину, главе семьи, затем - старикам, далее остальным членам семьи. Если хозяин в это время отсутствовал, то пиалу откладывали, оставляя для него. Когда он возвращался, то хозяйка варила ему новый чай, а оставленный для него чай сливала в свежесваренный. Хозяин жилища во время чаепития с домочадцами или при приеме гостей садился в сыртык базы у изголовья кровати (это место 
между сакральным местом жилища төр/тёр и изголовьем кровати, которая стояла на левой половине жилища), повернувшись лицом к очагу (Тюркские народы..., 2008: 71). Прибывшему гостю варили свежий чай. «Хозяйка наливала свежеприготовленный чай из котла в фаянсовую посуду, если ее не было, то в деревянную, и отдавала хозяину, а тот передавал ее гостю» (там же: 81). Если чай переливали в чайник-кувшин, то перед гостем его ставили ручкой по направлению к нему, что символизировало уважение и приглашение к длительному нахождению в гостях. По сложившему этикету, чай надлежало наливать на две трети чаши, подавать двумя руками или правой рукой, при этом левой поддерживая под правый локоть.

В семьях с достатком молочный чай был повседневным напитком, но не главной пищей, «в то время как в семье слабого достатка чай был нередко единственной пищей» (Потапов, 1969: 201). Молочный чай, который давали детям, назывался у тувинцев «хымыраан». Его готовили «как чай, но только настоящим чаем не заваривается. Для него просто кипят воду, подсаливают, добавляют молоко и снова кипятят» (там же: 201-202). Кроме молочного чая суттуг шай, приготовленного на основе базового рецепта, у тувинцев практиковалось приготовление «шаар» - чая, приготовленного во второй раз из чайных выжимок. В связи с этим хотелось бы отметить термин «шара» у западных тувинцев, маркирующий послед ребенка. В обоих случаях - и чай, и послед - смысловое значение терминов связано с остатком, «с тем, что осталось», выжимкой, оболочкой. Послед ребенка западные тувинцы закапывали в землю в юрте, где стояла кровать роженицы (Тюркские народы ..., 2008: 47), что указывает, по нашему мнению, на взаимосвязь понятий «женщина - хозяйка, мать, хранительница очага», «хозяйка огня, дарующая жизнь», «пища, приготовленная на очаге в родном доме».

Тувинцы пили чай в течение дня несколько раз: утром на завтрак, ближе к обеду после дойки кобылиц, занимавшей длительное время, в послеобеденное время и вечером. Употребление молочного чая, который был густым по составу и довольно сытным, часто заменяло один прием пищи. В теплое время года утром и вечером тувинцы пили либо просто молочный чай, либо подавали различные виды добавок как, например, крупы (талкан), пенки (өреме), сыр (быштак). В суровых зимних условиях при недостатке основного питания, чай обязательно пили с дополнительными видами пищи.

Талкан - мука крупного помола из обжаренных зерен ячменя (или пшеницы) - придавал сытость чаю. Основной способ употребления талкана - это подсыпание его в чашку чая, сваренного с солью и молоком. Если талкан употребляли в чае вместе с сушенным творогом ааржи, то получалось кушанье каaпчuир. Если же в чистый талкан или смешанный с ааржи добавляли масло, а затем клали в чай это называлось устуг талкан (Потапов, 1969: 194). Как отметил С. И. Вайнштейн, талкан из жареной пшеницы хоорган арбай считался «лакомой и питательной» пищей, «бедняки иногда, особенно в случаях голодовок, заменяли мукой, приготовленной из клубней дикорастущих растений» (Вайнштейн, 1991: 144). Практику использования вместо чая дикорастущих трав отмечали другие исследователи: «если в бедных семьях не было зеленого кирпичного чая, то использовали его заменители - дикорастущие травы» (Тюркские народы ..., 2008: 94). Рецептура такого чая была различной: чудан шай (в составе далган из пережаренных до темного цвета зерен ячменя, вода, молоко; в начале выпивали напиток, затем съедали жидкую кашицу из далгана), черлик шай (букв. «дикий чай», из высушенных листов кипрея узколистого, молока, соли), щенне шай (чай из корня пиона уклоняющегося, «марьин корень; предварительно высушенные корни обжаривали в масле до темного цвета, добавляли молоко, соль), сугмангыр шай (чай из смеси гераниложносибирской и плодов шиповника с молоком и солью) ${ }^{1}$ и т. д. ${ }^{2}$ Тем не менее, как отмечал Л. П. Потапов, молочный чай на основе зеленого кирпичного чая сутmуг шай был самым распространенным напитком в течение круглого года у тувинцев (Потапов, 1969: 201).

\section{Способы приготовления и употребления чая у калмыков}

У калмыков молочный чай үстә цз занимал особое место в рационе питания и обрядовой пище. Рецепт данного напитка калмыки привезли с собой из степей Центральной Азии, а позднее калмыцкий

\footnotetext{
${ }^{1}$ А также кызыл шай (букв. «красный чай», из коры лиственницы и молока), чай из коры караганы (для приготовления молочного чая использовали тевекудуруу («верблюжий хвост»- карагана гривастая), холахараган («караганник цвета латуни»), чымза шай (чай из корней бадана, молока), майырак шай (чай из смеси горца змеиного и «марьиного корня», молока), сараспан шай (чай из стебля ревеня с молоком и солью), ыт-кады шай (из плодов шиповника, вода, молоко), хадын бурулеринден шай (чай из березовых почек, вода, молоко), в качестве чайной заварки использовали листья облепихи, смородины, брусники ${ }^{2}$ Монгуш, Ч. Ч. (2012) Национальный напиток чай и его разновидности [Электронный ресурс] // Социальная сеть работников образования. URL: https://nsportal.ru/shkola/kraevedenie/library/2013/02/20/natsionalnyy-tuvinskiy-napitok-chay-i-egoraznovidnosti (дата обращения: 7.06.2019).
} 
чай хальмг цә, благодаря своим свойствам и вкусовым качествам, распространился среди народов Нижнего Поволжья и Северного Кавказа (Бакаева, 2003; Юсупов, 2003; Керейтов, 2005). Учитывая дороговизну чая и постоянную необходимость в его употреблении, относились к нему бережно, храня от повреждения, воздействия влаги и пыли в специальном кожаном мешке, украшенном национальными растительными узорами и подвешенном на деревянные жерди крыши уньн на женской стороне калмыцкого жилища. В этом мешке был тот чай, который непосредственно использовался в быту; запасы чая хранили в сундуках в тканевых или кожаных мешках уут.

О значении калмыцкого молочного чая в повседневном рационе калмыков подробно указал И. А. Житецкий: «когда встают, то готовят сейчас чай и пьют - это «эрюни ця». Часа через $4-5$ бывает второй чай - «хоене» (здесь - букв.после, позднее. - T. Ш., Е. А.). После этого часа через 2-3 бывает «юден хото» (полуденное кушанье) у зажиточных «махан», а у бедных опять чай. Перед вечером у зажиточных следует третий чай. Наконец вечером, когда стемнеет, «асахани хото»: у состоятельных людей - «махан», а у бедняков - старики пьют «ця», а прочие члены семьи едят «хёрмюк» или «будан» (Житецкий, 1893: 17).

Основной способ приготовления чая был прост: нарезали ножом от чайной плитки некоторое количество чая, которое клали в котел и затем давали вскипеть: кипячение воды без заварки было плохой приметой и предвещало предстоящею бедность. Продолжительность кипячения воды с заваркой занимала 5-10 минут. Затем добавляли молоко и соль по вкусу. Молоко для чая использовали коровье, овечье или верблюжье. Приготовление чая без молока было указанием на крайнюю степень обнищания. Чай без молока назывался хар цз (букв. 'черный чай’) или хоосн цз (букв. ‘пустой чай’).

Приготовленный чай процеживали через волосяную сетку шүр для того, чтобы «снять шар», т. е. извлечь положенный в котел разварившийся чай (шар). Этот шар не выбрасывали, а отжимали с помощью специальных деревянных тисков шавхр и впоследствии при новой варке добавляли к свежему чаю не только для экономии, но и для придания ему мягкого вкуса. В готовый чай добавляли немного масла, а «состоятельные семьи еще и пряности: лавровый лист, мускатный орех, гвоздику» (Калмыки, 2010: 196). Готовый чай разливали из котла или переливали в специальные высокие чайники без носика - домбо.

Приготовленный чай надо было смешать самрх, поднимая руку с половником и выливая чай обратно в котел. У калмыков есть поговорка: «цә самрх дутман зандрдг» (букв. - 'Чем больше мешать чай, тем гуще он станет, распуститься’). Движений при смешивании самрх, как считалось, нужно было сделать 77 или 99 раз, при этом, выполняя первые три движения самрх, необходимо было сначала описывать половником круг внутри котла с чаем и затем поднимать руку вверх, задерживая ее в верхней точке на непродолжительное время, чтобы «угостить» паром различных покровителей и божества. Исследователи отмечали сходную символику в традиционном многократном поднятии порций свежеприготовленного молочного чая в половнике, затем выливаемых обратно самрх и в совершении кропления водкой цацл: «если в обычае “самрх" молочный чай подносился божеству в виде пара, то в обряде “цацалх" водка, как результат конденсации пара, также предназначалась божеству с тем, чтобы в кибитке не было недостатка молока» (Бакаева, Гучинова, 1990: 63). В калмыцкой культуре число «7» связано с предками, их покровительством, а «9» символизирует достаток и благополучие, обилие скота, связано с символикой плодородия и огня. Есть версии, что чай необходимо было смешивать самрх 108 раз, но, вероятно, это связано с распространением буддизма и усилением его позиций среди калмыков.

Первую порцию приготовленного утром чая калмыки обязательно наливали в жертвенную чашу и ставили на алтаре как подношение предкам дееж, позднее его давали выпить маленьким детям. Интересны в этом контексте сведения У.Д.Душана о подношении чаем у калмыков: ««Деджи» приносились предкам ... почти такое же значение имело и другое явление, так называемое «зулуөргөхю». Каждый калмык, сварив чай, прежде, чем его пить, брал немного чаю в чашке шел к двери, затем он снимал шапку, одну (правую) ногу выставлял за дверь и правой рукой сбрызгивал чай над дверью. «Зул-өргөхю» делали только из чая, который должен быть сварен до 12 часов дня» (Душан, 1976: 76).

Во время чаепития в кругу семьи сначала угощали чаем старших по возрасту. Считалось, что утренний чай несет в себе заряд удачи, что нашло отражение в пословице: өрүни цзәһән ууһад hархла, керг күцдг (букв. 'Если выпьешь утренний чай, то дела исполнятся'. Чай подавали в небольших деревянных чашках $a a h$, держа пиалу двумя руками и ни в коем случае не касаясь пальцами краев 
чаши чимкх/чимкәд (букв. прищепнув), что было связано с солярной символикой и домашнего очага, и, соответственно, символикой целостности круга, а также отрицательных последствий вследствие ее нарушения. Поэтому строго запрещалось наливать чай в чашу с надломленным краем (Хабунова, 2009: 20). Непосредственно перед употреблением чая старшие в семье совершали троекратное кропление чаем безымянным пальцем правой руки (вариант - мизинцем и большим пальцем правой руки) как подношение различным духам.

Согласно традициям гостеприимства калмыков, пришедшего в гости следовало угостить чаем, приготовленным в его присутствии. Считалось хорошей приметой, если сразу после приготовления чая в жилище приходил гость. Если для угощения гостя чай переливали в чайник донбо, то его снова кипятили. Хозяйка должна была придерживаться правил при приготовлении и подношении калмыцкого чая для того, чтобы не умалить достоинства своего супруга и семьи, показать себя гостеприимной хозяйкой с собственными кулинарными способностями. Если гостем был духовное лицо или государственный чиновник, то ритуал подношения чая совершался хозяином дома. По сведениям У. Д. Душана, чай гостю у калмыков мог подносить младший в семье, «причем считалось нетактичным и вместе с темдурным предзнаменованием, если подносящий прольет хотя бы несколько капель из чаши. При таком случае молодой человек получал замечание, и чашка доливалась, чтобы возвратить счастье пьющего человека» (Душан, 1976: 53).

У калмыков существовало множество других рецептов приготовления чая, так как, кроме утоления жажды, он мог заменить один прием пищи, особенно в сочетании с мучными изделиями боорцг. Так, калмыки готовили хуурсн цә (букв.'обжаренный чай’) - небольшое количество муки обжаривали в бараньем жиру и добавляли в готовый чай; жомба - густой чай из крепкой заварки, заправленный сливками или небольшим количеством молока; махта цә (букв.'чай с мясом') - чай, который готовили на основе мясного бульона или готовый чай, в который в конце варки добавляли кусочки мяса с бульоном, шуурмгта цә - чай, в который добавляли шкварки бараньего жираи т. д. По степени густоты различали шиңгн цзә - легкий, слабозаваренный чай, өткн цз - густой, насыщенный, щедро заправленный маслом или сливками, агта цз - чай, приготовленный на крепкой заварке с минимальным количеством молока (Пюрбеев, 1996: 107-110).

Также у калмыков название молочного чая зависело от его использования в той или иной жизненной ситуации, например, чай, сваренный по случаю изготовления войлока, назывался ишкән ццә (букв.'чай войлока'), өвин цзә - чай для благословения приданого невесты перед его выносом из дома ее родителей, который варили представители стороны жениха, манз цз - чай, который подавался священнослужителям во время молитвы (там же: 107-110). Наименование молочного густого чая жомба/жомба цә (от тиб. цзампа) связывают у калмыков с традицией чаепития буддийских священнослужителей - выходцев из Монголии и Тибета - с обжаренным ячменным зерном, перетертым в муку. Распространенное в фольклоре калмыков определение чая улан зандн цә (букв.'расный сандаловый чай’) ассоциировалось в повседневной жизни калмыков с жомба как густым крепким чаем с небольшим добавлением молока или сливок из-за чего он казался красноватого цвета. В калмыцких народных сказках и в эпосе «Джангар», чаепитие богатырей заканчивается отдыхом, где качество сна определяется воздействием выпитого чая и богатырь засыпает «сур мет сунад, суха мет улаһад» (букв.'растянувшись как ремень, раскрасневшись как таволожник').

\section{Сохраняя традищии}

В современных культурных традициях тувинцев и калмыков молочный чай занимает одно из главных мест не только в пище, но и в обрядовых комплексах и праздничной культуре. Молочный чай является одним из основных маркеров этничности у калмыков и тувинцев. Каждый представитель данных этносов скажет о своем чае «наш чай», «калмыцкий чай», «тувинский чай», при этом, не подчеркивая, что это именно молочный чай - «калмыцкий молочный чай» или «тувинский молочный чай». Просто - хальмг цә, просто - сүттүг шай. В таком обозначении чая есть для каждого тувинца и калмыка «свой мир», в котором отражаются исторические и этнические особенности, картина мира, этикет, социальные роли и гендерные взаимоотношения, особенности календарной обрядности и обрядов жизненного цикла. И в настоящее время калмыки и тувинцы считают, что молочный чай это высокоэнергетический напиток, придающий сил, лекарство от многих болезней, сытное блюдо, которое может заменить один прием пищи. 
Конечно же, в современных реалиях происходят некоторые изменения в рецептуре и способах приготовления молочного чая у тувинцев и калмыков, например, в пакетированный чай, заваренный обычным способом в кружке, добавляют немного сливок или молока и соли. Никого уже не удивить пакетиком растворимого молочного чая с солью фабричного производства, но его использование - это часто такая же вынужденная мера как «пакетный чай в кружке с молоком» в отсутствие возможности приготовить «тот самый чай», «свой чай». Постоянная востребованность в употреблении молочного чая обусловила его наличие в меню во всех кафе и ресторанах обеих республик.

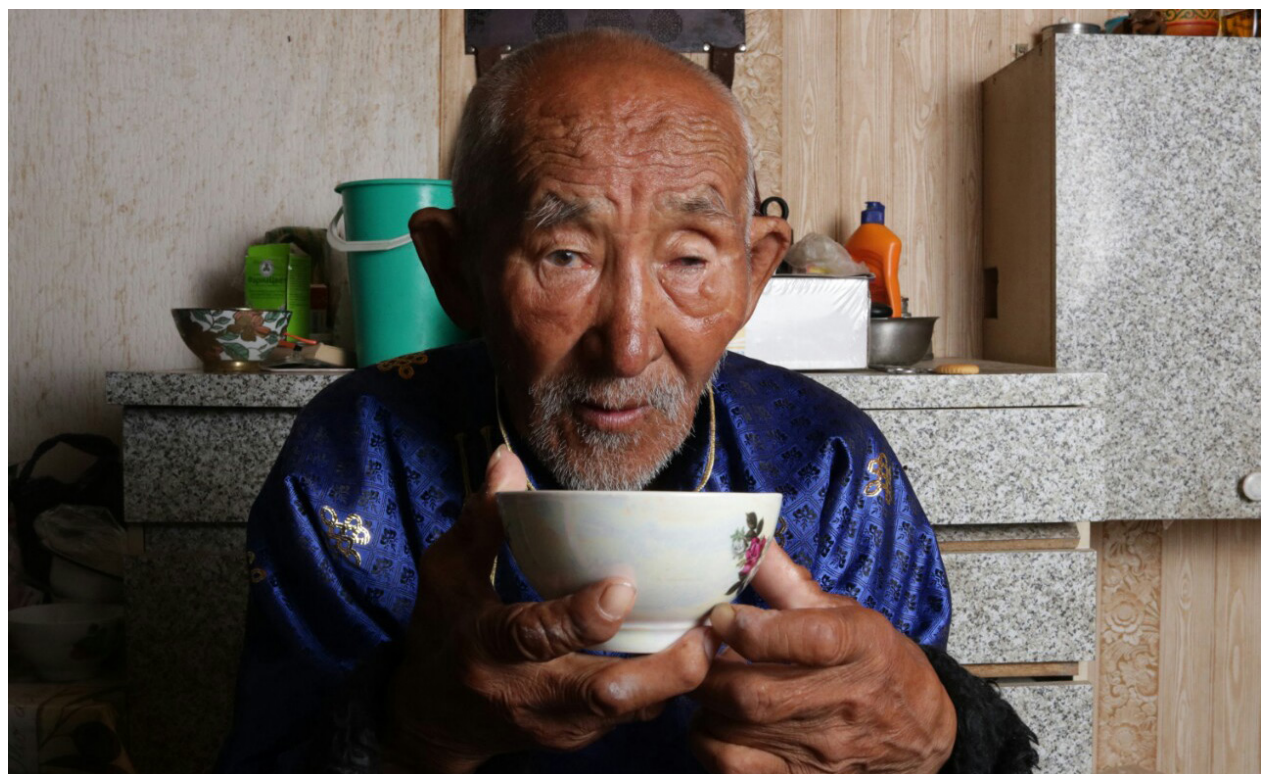

Фото 1. Тувинеи с пиалой чая. Село Дус-Даг Овюрского района Республики Тыва. Фото Е. Айыжы, 2017 г.

Photo 1. A Tuvan man holding a bowl of tea. Dus-Dag village, Ovyursky District, Tuva Republic. Photo by E. Aiyzhy, 2017.

У тувинцев традиция приготовления молочного чая из зеленого плиточного сүттүг шай не прерывалась, сохраняется и является преобладающей, несмотря на то, что в магазинах представлен широкий выбор чая и по сортам, и по производителям. Тувинцы сохраняют множество рецептов приготовления молочного чая, как на основе чая, так и на основе трав. Есть отличия в рецептуре и способах приготовлениях молочного чая в зависимости от района проживания на территории республики, да и у каждой хозяйки получается свой уникальный молочный чай. Поэтому, думается, что появившаяся традиция проведения ежегодного конкурса «Фестиваль чая» будет продолжена и расширена количеством участников, включая молодежь.

В истории чая у калмыков в XX в. есть печальные страницы, обусловленные историческими событиями. Так, в первые годы нахождения в ссылке (1943 - 1956 гг.) калмыки боролись за выживание и не имели возможности употреблять им привычный чай. Позднее, начиная с 50-х гг. XX века в местах поселения калмыков стали продавать зеленый кирпичный чай, «спрос породил предложение». После возвращения в Калмыкию основными ингредиентамитрадиционного калмыцкого молочного чая на долгие годы стали зеленый плиточный и черный кирпичный грузинские чаи, что было обусловлено его низкой ценовой категорией и развитием чайной промышленности в СССР. Как отмечали знатоки чая, «плиточный чай отличается от кирпичного, прежде всего, характером материала. Для изготовления плиточных чаев идет крошка, высевки, словом, второстепенные продукты чайной промышленности, в то время как производство кирпичного чая базируется на второстепенном сырье чайного хозяйства» (Пою степной нектар...2016: 64). С этого же времени калмыки стали варить калмыцкий чай, смешивая черный и зеленый чаи для заварки.

У современных калмыков, как и у тувинцев, существует большое количество рецептов приготовления молочного чая. Кроме того, как считают калмыки, по соотношению ингредиентов в калмыцком чае можно определить из какого района родом хозяйка, приготовившая чай, например: если соленый и густой - то из северного, много молока - западного. В туристическом бизнесе калмыцкий чай один из брендов Республики Калмыкия, наряду с буддийскими центрами, шахматами, тюльпанами и «мраморным» мясом. 


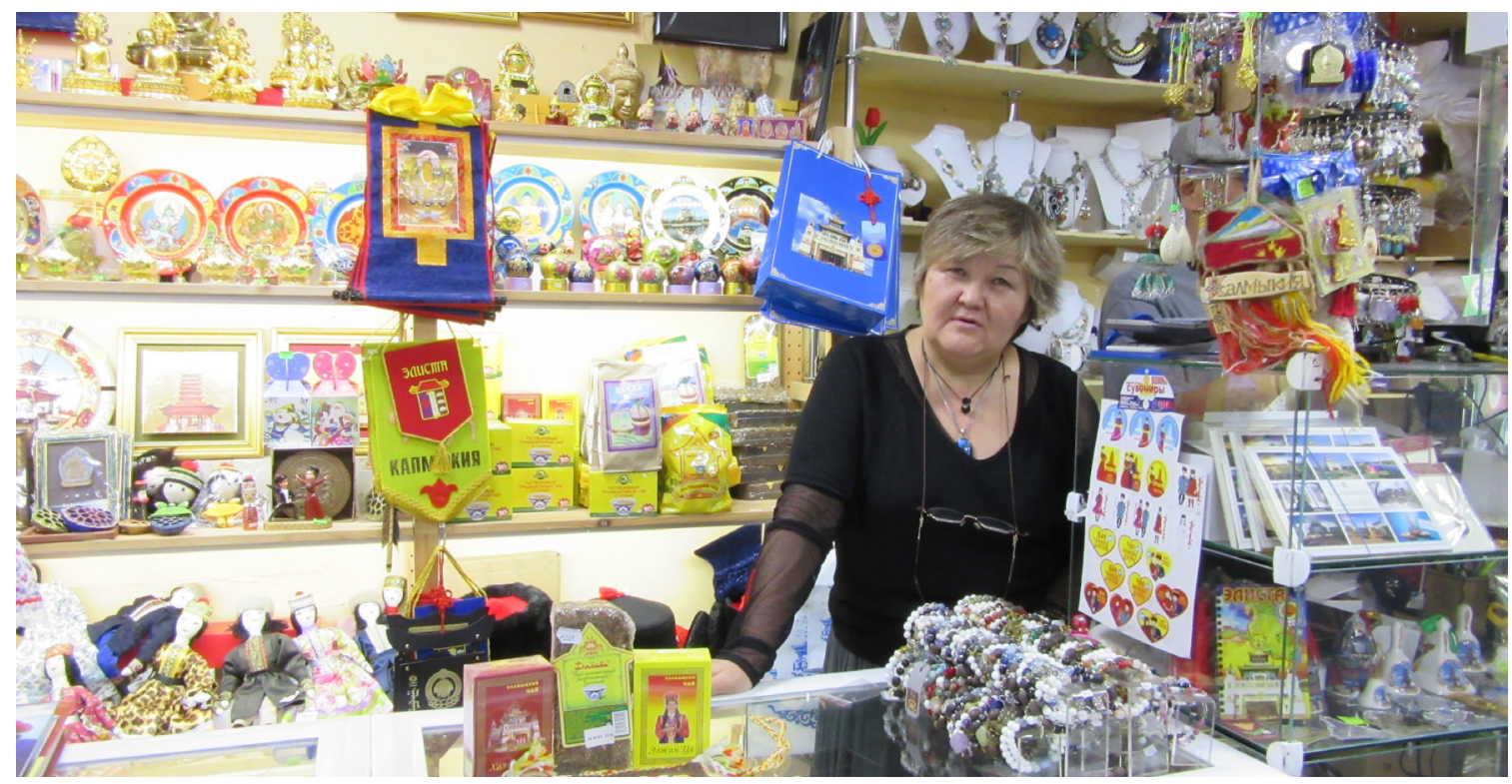

Фото 2. Продажа калмыцкого чая в сувенирном магазине «Кишгтя белг» 2. Элисты.

На фото владелец магазина Е. Киштанова. Фото Т. Шараевой, 2019 г.

Photo 2. Kalmyk tea exposed for sale, 'Kishgtya Belg' gift shop, Elista. The picture depicts the shop owner E. Kishtanova. Photo by T. Sharaeva, 2019/

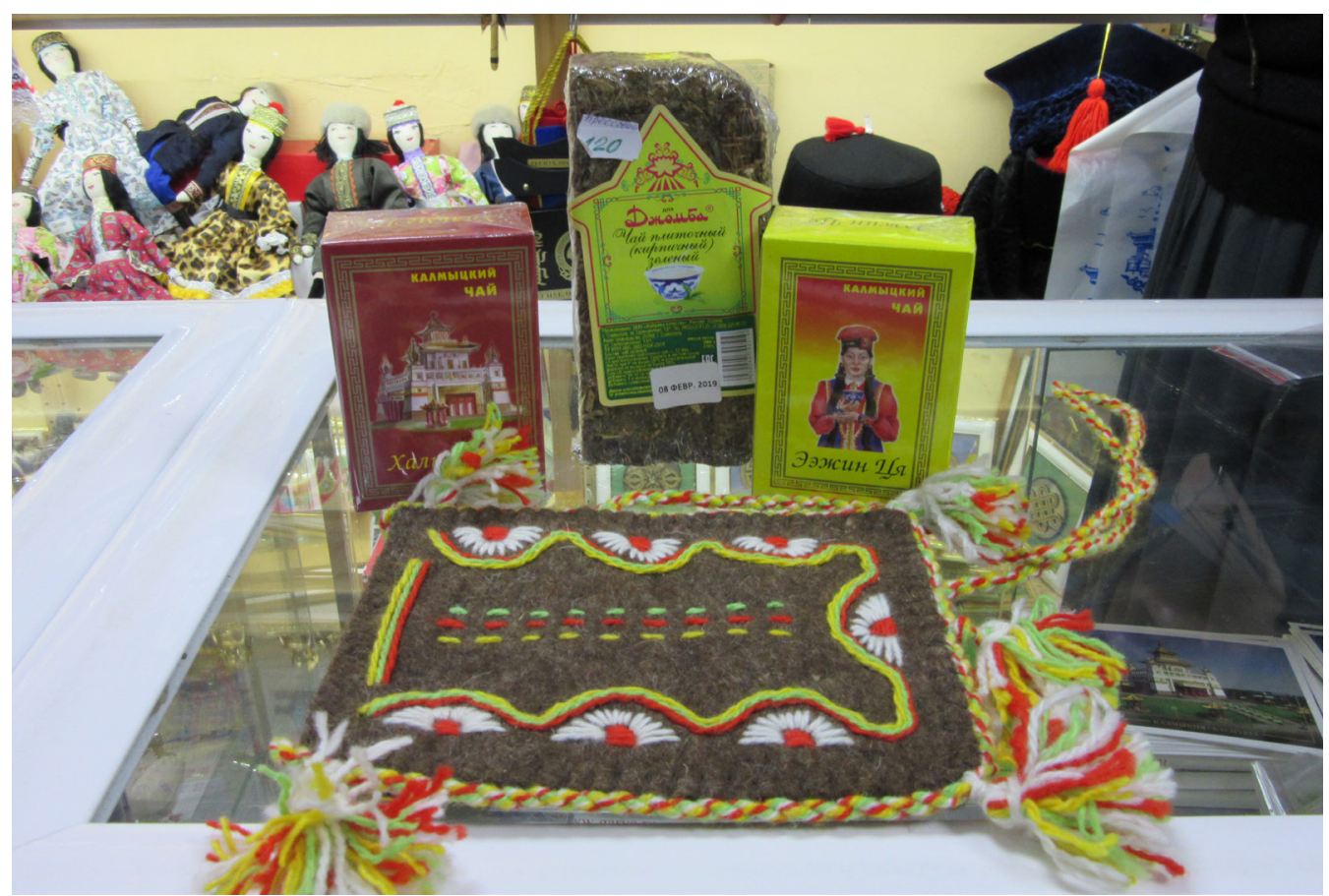

Фото 3. Пакеты калмыцкого чая в продаже, г. Элиста. Фото Т. Шараевой, 2019 г.

Photo 3. Packages of Kalmyk tea for sale, Elista. Photo by T. Sharaeva, 2019.

\section{Заключение}

Чай играл большую роль в питании калмыков и тувинцев в традиционном быту. Несмотря на распространение в культурных традициях обоих народов разными путями, он сумел занять позицию одного из основных способов коммуникации, поддержания традиций и исторической памяти, что позволило ему не только удержать свои позиции в культурном пространстве этих тюрко-монгольских народов, но стать в современных реалиях одним из значимых этнических маркеров. 
Изучение и анализ материалов о чае у калмыков и тувинцев позволили выявить существенные особенности в традиционных практикахприготовления и употребления. Так, например, в традиционном тувинцы измельчали чай ступкой перед приготовлением, а калмыки крошили ножом; тувинцы чайную заварку опускали в воду после закипания воды в котле, калмыки - в холодную воду изначально, что было связано с народными представлениями о пустоте и нищете; при приготовлении чая у тувинцев процесс смешивания ингредиентов приемом саарар происходил, пока котел с чаем находился на очаге, у калмыков - процесс самрх производился после снятия котла. Отличием в рецептуре молочного чая является использование тувинцами местных трав в качестве заварки, что связано, в первую очередь, с условиями проживания в определенных природно-географических зонах и народными традициями.

Определенные различия проявляются в числовых кодах тувинцев и калмыков. В процессе приготовления молочного чая у тувинцев преобладающее значение имел культ огня и очага, проявляющийся через число «сорок», а у калмыков - число «семь» как символ предков и «девять» как символ достатка, хотя использование ритуальной ложки «девятиглазки» у тувинцев также связано с ритуалами испрашивания благополучия у различных покровителей.

\section{СПИСОК ЛИТЕРАТУРЫ}

Алексеева, П. Э. (1999) Рассказы о калмыцком чае // Теегин герл. № 1. С. 106-109.

Арутюнов, С. А. (2001) Основные пищевые модели и их локальные варианты у народов России // Традиционная пища как выражение этнического самосознания / отв. ред. С. А. Арутюнов, Т.Д. Воронина. М. : Наука. 293 с. С. 10-17.

Бакаева, Э. П., Гучинова, Э.-Б. М. (1990) Алкоголь в обрядовых действиях у калмыков // Проблемы изучения традиций в культуре народов мира / отв. ред. О. И. Брусина, Н. Я. Дараган. М. : Институт этнографии АН СССР. Вып. 1. 119 с. С. 57- 67.

Бакаева, Э. П. (2003) Калмыцкий чай у ставропольских туркмен // Монголоведение в новом тысячелетии: (к 170-летию организции первой кафедры монгольского языка в России). Материалы международной научной конференции (22-26 сент. 2003 г.) / отв. ред. Г. М. Борликов. Элиста : Калмыцкий государственный университет. 320 с. С. 234-238.

Бутанаев, В. Я., Монгуш, Ч. В. (2005) Архаические обычаи и обряды саянских тюрков / отв. ред. И. Н. Гемуев. Абакан : Издательство Хакасского государственного университета им. Н. Ф. Катанова. 200 c.

Борджанова, Т. Г. (2000) Еще раз о калмыцком чае // ALTAICA. Вып. VII. M. : Институт востоковедения PAH. С. 36-46.

Вайнштейн, С. И. (1961) Тувинцы-тоджинцы. Историко-этнографические очерки / отв. ред. Л. П. Потапов. М.: Издательство Восточной литературы. 218 с.

Вайнштейн, С. И. (1991) Мир кочевников центра Азии. М.: Наука. 294 с.

Грум-Гржимайло, Г. Е. (1926) Западная Монголия и Урянхайский край: Антропологический и этнографический очерк этих стран. Л. : Государственное Русское географическое общество. Т. 3. Вып. 1. 412 c.

Дацышен, В. Г. (2011) Китайцы в Туве в начале XX века [Электронный ресурс] // Новые исследования Тувы. № 1. URL: https://nit.tuva.asia/nit/article/view/446/821 (дата обращения: 18.06.2019).

Донгак, С. Ч. (2018) Мал ыдыктаар тыва ёзулалдар. Тувинские обряды освящения скота. Кызыл : ИПП «Журналист». 51 с. (На тув. и рус. яз.).

Душан, У. Д. (1976) Обычаи и обряды дореволюционной Калмыкии // Этнографический сборник. Вып. 1. Элиста : КНИИЯЛИ. С. 5-89.

Житецкий, И. А. (1893) Очерки быта астраханских калмыков (этнографические наблюдения 18841886 гг.). М. : Типография М. Г. Волчанинова. 87 с.

Исторические путешествия. Извлечения из мемуаров и записок иностранных и русских путешественников по Волге в XV-XVIII веках (1936) / сост. В.Алексеев. Сталинград : Краевое книгоиздательство. 326 с.

Калмыки (2010) / отв. ред. Э. П. Бакаева, Н. Л. Жуковская; Ин-т этнологии и антропологии им. Н. Н. Миклухо-Маклая РАН, КИГИ РАН. М.: Наука. 568 с. 
Керейтов, Р. Х. (2005) Чай в пище ногайцев // Вестник Калмыцкого института гуманитарных исследований РАН. № 19. С. 188-191.

Кон. Ф. Я. (1936) За 50 лет. М.: Советский писатель. 2-е изд. 355 с.

Ларина, Е. И., Наумова, О. Б. (2008) Традиции чаепития у казахов // Хмельное и иное: напитки народов мира / отв. ред. С. А. Арутюнов, Т. А. Воронина. М. : Наука. 504 с. С. 221-248.

Липинская, В. А. (2008) Чай в русской культуре (XVI - начало XX века) // Хмельное и иное: напитки народов мира / отв. ред. С. А. Арутюнов, Т. А. Воронина. М. : Наука. 504 с. С. 20-44.

Небольсин, П.И. (1852) Очерки быта калмыков Хошеутовского улуса. СПб. : Типография Карла Крайя. 192 c.

Нефедьев, Н. А. (1834) Подробные сведения о волжских калмыках, собранные на месте Н. Нефедьевым. СПб. : Типография Карла Крайя. 290 с.

Потанин, Г. Н. (1883) Очерки Северо-западной Монголии: Результаты путешествия, исполненного в 1876-1877 г. по поручению Императорского Русского географического общества членом-сотрудником оного Г. Н. Потаниным : в 4 вып. СПб. : Типография В. Безобразова и Кㅇ. 372 с.

Потанин, Г. Н. (2003) Заметки о семейном, общественном и религиозном быте // Традиционная культура тувинцев глазами иностранцев (конец XIX - начало XX века) (2003) / подг. текстов, предисл., комм. А. К. Кужугет. Кызыл : Тувинское книжное изд-во. 224 с. С. 23-29.

Потапов, Л. П. (1969) Очерки народного быта тувинцев. М. : Наука, Главная редакция восточной литературы. 402 с.

Пою степной нектар - пою Калмыцкий чай (2016) / сост. А. Т. Баянова, П. Э. Алексеева. Элиста : Калмыцкое книжное издательство. 191 с. (На калм. и русс.яз.)

Пюрбеев, Г. Ц. (1996) Толковый словарь традиционного быта калмыков. Элиста: Калмыцкое книжное издательство. $176 \mathrm{c.}$

Семь звезд: калмыцкие легенды и предания (2004) / сост., пер., вступ. ст., коммент. Д. Э. Басаева. Элиста: Калмыцкое книжное издательство. 415 с.

Смирнов, П. А. (1999) Путевые записки по Калмыцким степям Астраханской губернии / ред. А. Б. Лиджиев. Элиста: Калмыцкое книжное издательство. 248 с.

Тюркские народы Восточной Сибири (2008) / отв. ред. Д. А. Функ, Н. А. Алексеев. М. : Наука. 422 с.

Хабунова, Е. Э. (2009) О чайной церемонии калмыков. Волгоград: ОАО ИПК Царицын. 35 с.

Эрдниев, У. Э. (1970) Калмыки (конец XIX - начало XX в.). Историко-этнографические очерки / ред. Г. Г. Стратанович. Элиста: Калмыцкое книжное издательство. 312 с.

Юсупов, М.М.(2003) Калмыцкий чай учеченцев// Монголоведение в новом тысячелетии:(к 170-летию организции первой кафедры монгольского языка в России). Материалы международной научной конференции (22-26 сент. 2003 г.). / отв. ред. Г. М. Борликов. Элиста: Калмыцкий государственный университет. 320 с. С. 220-222.

Яковлев, Е. К. (1900) Этнографический обзор инородческого населения долины Южного Енисея и объяснительный каталог Этнографического отдела Музея. Минусинск: Тип. В. И. Корнакова. 357 с.

Дата поступления: 01.09.2019 2.

\section{REFERENES}

Alekseeva, P. E. (1999) Rasskazy o kalmytskom chae [Stories about the Kalmyk tea]. Teegin gerl, no. 1, pp. 106-109. (In Russ.).

Arutyunov, S. A. (2001) Osnovnye pishchevye modeli i ikh lokal'nye varianty u narodov Rossii [Peoples of Russia: basic food models and their local versions]. In: Traditsionnaya pishcha kak vyrazhenie ehtnicheskogo samosoznaniya [Traditional food as an instrument of ethnic identity]. Ed. by S. A. Arutyunov, T. D. Voronina. Moscow, Nauka. 293 p. Pp. 10-17. (In Russ.).

Bakaeva, E. P., and Guchinova, E.-B. M. (1990) Alkogol' v obryadovykh deistviyakh u kalmykov [Alcohol in ceremonial activities of the Kalmyks]. In: Problemy izucheniya traditsii $v$ kul'ture narodov mira [Traditions in world cultures: research problems]. Ed. by O. I. Brusina, N. Ya. Daragan. Moscow, Institute of Ethnography (USSR Academy of Sciences). Is. 1. 119 p. Pp. 57- 67. (In Russ.). 
Bakaeva, E. P. (2003) Kalmytskii chai u stavropol'skikh turkmen [Kalmyk tea among Stavropol Turkmens]. In: Mongolovedenie v novom tysyacheletii: ( $k$ 170-letiyu organiztsii pervoi kafedry mongol'skogo yazyka v Rossii) [Mongolian studies in the new millennium (celebrating the $170^{\text {th }}$ anniversary of the establishment of the first Russia's university-based Mongolian language department)]. Proceedings of the international scientific conference (September 22-26, 2003). Ed. by G. M. Borlikov. Elista, Kalmyk State University. 320 p. Pp. 234-238. (In Russ.).

Butanaev, V. Ya., and Mongush, Ch. V. (2005) Arkhaicheskie obychai i obryady sayanskikh tyurkov [Archaic traditions and rituals of the Sayan Turks]. Ed. by I. N. Gemuev. Abakan, Katanov Khakas State University. 200 p. (In Russ.).

Bordzhanova, T. G. (2000) Eshche raz o kalmytskom chae [Once again about the Kalmyk tea]. ALTAICA. Is. VII. Moscow, Institute of Oriental Studies of RAS. Pp. 36-46. (In Russ.).

Vainshtein, S. I. (1961) Tuvintsy-todzhintsy. Istoriko-ehtnograficheskie ocherki [The Tozhu Tuvans: historical and ethnographic sketches]. Ed. by L. P. Potapov. Moscow, Vostochnaya Literatura. 218 p. (In Russ.).

Vainshtein, S. I. (1991) Mir kochevnikov tsentra Azii [The world of nomads inhabiting Asia's center]. Moscow, Nauka. 294 p. (In Russ.).

Grum-Grzhimailo, G. E. (1926) Zapadnaya Mongoliya i Uryanhajskii krai [Western Mongolia and the Uriankhai Contry]. Vol. 3. Part 1. An anthropological and ethnographical sketch of these countries by G. Grum-Grzhimailo. Leningrad, State (Russian) Geographical Society. 412 p. (In Russ.).

Datsyshen, V. G. (2011) Kitaitsy v Tuve v nachale XX veka [Chinese in Tuva in early $20^{\text {th }}$ century]. The New Research of Tuva, no. 1, pp. 143-159. (In Russ.). [online] Available at: https://nit.tuva.asia/nit/article/ view/446/821 (access date: 18.06.2019).

Dongak, S. Ch. (2018) Mal ydyktaar tyva ezulaldar. Tuvinskie obryady osvyashcheniya skota [Livestock blessing rituals of the Tuvans]. Kyzyl, Zhurnalist. 51 p. (In Tuv. and Russ.).

Dushan, U. D. (1976) Obychai i obryady dorevolyutsionnoi Kalmykii [Traditions and rituals of pre-revolutionary Kalmykia]. In: Etnograficheskii sbornik [Collected ethnography research papers]. Is. 1. Elista, KNIIYaLI. Pp. 5-89. (In Russ.).

Zhitetsky, I. A. (1893) Ocherki byta astrakhanskikh kalmykov (ehtnograficheskie nablyudeniya 18841886 gg.) [Astrakhan Kalmyks: sketches of everyday life (ethnographic observations of 1884-1886)]. Moscow, M. G. Volchaninov. 87 p. (In Russ.).

Istoricheskie puteshestviya. Izvlecheniya iz memuarov i zapisok inostrannykh i russkikh puteshestvennikov po Volge $v$ XV-XVIII vekakh [Historical travels/ Excerpts from memoirs and travel notes of foreigners and Russians to have travelled along the Volga in the $15^{\text {th }}-18^{\text {th }}$ centuries] (1936). Comp. by V. Alekseev. Stalingrad, Regional Book Publ. 326 p. (In Russ.).

Kalmyki [The Kalmyks] (2010). Ed. by E. P. Bakaeva, N. L. Zhukovskaya. Miklouho-Maclay Institute of Ethnography and Anthropology of RAS, Kalmyk Humanities Research Institute of RAS. Moscow, Nauka. 568 p. (In Russ.).

Kereitov, R. Kh. (2005) Chai v pishche nogaitsev [Tea in meals of the Nogais]. Bulletin of the Kalmyk Institute for Humanities of the RAS, no. 19, pp. 188-191. (In Russ.).

Kon, F. Ya. (1936) Za 50 let [Within 50 years]. Moscow, Sovetskii Pisatel. $2^{\text {nd }}$ ed. 355 p. (In Russ.).

Larina, E. I., and Naumova, O. B. (2008) Traditsii chaepitiya u kazakhov [Tea traditions of the Kazakhs]. In: Khmel'noe i inoe: napitki narodov mira [Alcohol and other things: national beverages of the world]. Ed. by S. A. Arutyunov, T. A. Voronina. Moscow, Nauka. 504 p. Pp. 221-248. (In Russ.).

Lipinskaya, V. A. (2008) Chai v russkoi kul'ture (XVI - nachalo XX veka) [Tea in Russian culture $\left(16^{\text {th }}-\right.$ early $20^{\text {th }} \mathrm{Cc}$.)]. In: Khmel'noe i inoe: napitki narodov mira [Alcohol and other things: national beverages of the world]. Ed. by S. A. Arutyunov, T. A. Voronina. Moscow, Nauka. 504 p. Pp. 20-44. (In Russ.).

Nebolsin, P. I. (1852) Ocherki byta kalmykov Khosheutovskogo ulusa [Kalmyks of Khosheutovsky District (Ulus): sketches of everyday life]. St. Petersburg, Karl Krai. 192 p. (In Russ.).

Nefediev, N. A. (1834) Podrobnye svedeniya o volzhskikh kalmykakh, sobrannye na meste N. Nefed'evym [Detailed data about the Volga Kalmyks collected on site by N. Nefediev]. St. Petersburg, Karla Krai. 290 p. (In Russ.).

Potanin, G.N. (1883) Ocherki Severo-zapadnoi Mongolii: Rezul'taty puteshestviya, ispolnennogo $v$ 1876-1877 g. po porucheniyu Imperatorskogo Russkogo geograficheskogo obshchestva chlenov sotrudnikom onogo 
G. N. Potaninym [Sketches of Northwestern Mongolia: summarizing the results of the 1876-1877 trip commissioned by the Imperial Russian Geographical Society and undertaken by its employed associate G. N. Potanin]. In 4 vols. St. Petersburg, V. Bezobrazov \& $\mathrm{C}^{\circ} .372$ p. (In Russ.).

Potanin, G. N. (2003) Zametki o semeinom, obshchestvennom i religioznom byte [Sketches of family, social and religious activities]. In: Traditsionnaya kul'tura tuvintsev glazami inostrantsev (konets XIX - nachalo $X X$ veka) [Tuvan traditional culture in the eyes of foreigners (late 19th - early 20 th $c c$. .)] (2003). Prep., foreword, comment. by A. K. Kuzhuget. Kyzyl, Tuvan Book Publ. 224 p. Pp. 23-29. (In Russ.).

Potapov, L. P. (1969) Ocherki narodnogo byta tuvintsev [The Tuvans: sketches of the folk lifestyle and related household activities]. Moscow, Nauka, GRVL. 402 p. (In Russ.).

Poyu stepnoi nektar - poyu Kalmytskii chai [I praise the steppe nectar - I praise the Kalmyk tea] (2016). Comp. by A. T. Bayanova, P. E. Alekseeva. Elista, Kalmyk Book Publ. 191 p. (In Kalm. and Russ.).

Pyurbeev, G. Ts. (1996) Tolkovyi slovar' traditsionnogo byta kalmykov [Traditional everyday life of the Kalmyks: an explanatory dictionary]. Elista, Kalmyk Book Publ. 176 p. (In Kalm. and Russ.).

Sem' zvezd: kalmytskie legendy i predaniya [The Seven Stars: Kalmyk legends and tales] (2004). Comp., transl., foreword, comment. by D. E. Basaev. Elista, Kalmyk Book Publ. 415 p. (In Russ.).

Smirnov, P. A. (1999) Putevye zapiski po Kalmytskim stepyam Astrakhanskoi gubernii [Across the Kalmyk steppe of Astrakhan Governorate: travel notes]. Ed. by A. B. Lidzhiev. Elista, Kalmyk Book Publ. 248 p. (In Russ.).

Tyurkskie narody Vostochnoi Sibiri [Turkic peoples of Eastern Siberia] (2008). Ed. by D. A. Funk, N. A. Alekseev. Moscow, Nauka. 422 p. (In Russ.).

Khabunova, E. E. (2009) O chainoi tseremonii kalmykov [About the Kalmyk tea ceremony]. Volgograd, Tsaritsyn. 35 p. (In Russ.).

Erdniev, U. E. (1970) Kalmyki (konets XIX - nachalo XX v.). Istoriko-ehtnograficheskie ocherki [The Kalmyks (late $19^{\text {th }}$-early $20^{\text {th }}$ cc.): historical and ethnographic essays]. Ed. by G. G. Stratanovich. Elista, Kalmyk Book Publ. 312 p. (In Russ.).

Yusupov, M. M. (2003) Kalmytskii chai u chechentsev [Kalmyk tea among the Chechens]. In: Mongolovedenie $v$ novom tysyacheletii: ( $k$ 170-letiyu organiztsii pervoi kafedry mongol'skogo yazyka $v$ Rossii) [Mongolian studies in the new millennium (celebrating the $170^{\text {th }}$ anniversary of the establishment of the first Russia's university-based Mongolian language department)]. Proceedings of the international scientific conference (September 22-26, 2003). Ed. by G. M. Borlikov. Elista, Kalmyk State University. 320 p. Pp. 220-222. (In Russ.).

Yakovlev,E.K.(1900)Etnograficheskii obzor inorodcheskogo naseleniya doliny Yuzhnogo Eniseya i ob"yasnitel'nyi katalog Etnograficheskogo otdela Muzeya [An ethnographic review of the South Yenisei Valley and the explanatory catalogue of the Museum's Ethnography Research Department]. Minusinsk, V. I. Kornakov. 357 p. (In Russ.). 